\title{
Assessment of groundwater quality and its suitability for agricultural uses in Kifri
}

\author{
Abdulmutalib Raafat Sarhat \\ Assistant Lecturer, Chemistry Dept., University of Garmian, Kurdistan Region, Iraq
}

\section{Abstract}

Groundwater is regarded as one of the main water sources in a number of countries in the world to supply cities and urban areas with water for domestic, agricultural and industrial uses. That is because of lack of surface water and rainfall quantities. Therefore, the levels and quantities of groundwater should be observed regularly. The quality of groundwater is mainly influenced by the effects of anthropogenic sources. The aim of this study is to evaluate the quality of groundwater in Kifri district. In this case fifteen groundwater samples were collected at identical locations from deeper wells in order to investigate their quality parameters such as: $\mathrm{pH}$, Electric conductivity, total dissolved solids, concentration of soluble ions and some others. The results of the concentrations were measured and interpreted with some irrigation indexes such as sodium percent (SP), sodium adsorption ratio (SAR), residual sodium carbonate (RSC), magnesium hazard ( $\mathrm{MH} \%)$, and Kelly's ratio (KR).

The results reveal that all of groundwater samples have SAR less than (10); it is indicating water class to be of excellent quality. Also, all the samples have RSC less than the permissible (1.5). However, it is observed that $(6.67 \%)$ of the samples have $\mathrm{MH}$ ratio values greater than (50). Presence of more magnesium in irrigation water compared to calcium leads to increase the degree of magnesium saturation thus decrease soil productivity. The results also reveal that the samples have values of (SP) less than (60\%). Overall, it indicates that the quality of $(93.33 \%)$ of the samples falling under excellent category for irrigation purposes. 


\section{Introduction}

Shortage of surface water and rainfall quantities, especially in the hot seasons; make groundwater as a basic source for irrigation. Therefore, the quality of the groundwater must be observed. The chemical composition of groundwater is mainly relying on some factors which include composition of precipitation, leachate from landfill sites, irrigation return flow and domestic and industrial wastes, climate and topography. All those factors combine together to create a range of water types that change temporally and spatially (Güler et al., 2002). The quality of groundwater may vary from place to place and with the water table depth. So, considerable variation can be found even in the same area. Groundwater is regarded as an important water source for drinking and agriculture purposes in the study area. Therefore, irrigation water quality is very important for field crop production. However, irrigation water with poor quality can affect yields and soil physical properties (Talukder et al., 1998). Variances plants require a variance of water qualities, therefore; assessment the quality of irrigation water is essential to contribute to actual management and groundwater resources utilization. In this research, a number of chemical qualities of groundwater have been assessed and dissimilar index methods were used such as SP, SAR, RSC, KR, and MH with reference to their suitability for irrigation uses.

\section{Study Area}

Kifri district is located about $100 \mathrm{Km}$ southeast of Kirkuk city and geographically lies between northern latitudes from $\left(\begin{array}{lll}34^{\circ} 27^{\prime} 24^{\prime \prime}-35^{\circ} 10^{\prime} 17^{\prime \prime}\end{array}\right)$ and eastern longitudes from ( $\left.44^{\circ} 31^{\prime} 4^{\prime \prime}-45^{\circ} 16^{\prime} 52^{\prime \prime}\right)$. Its elevation ranges between (130-755) $\mathrm{m}$ above the sea level. The study area is classified within semi-arid area, so that; precipitation is of short duration and its mean annual is less than $300 \mathrm{~mm}$.

\section{Materials and Methods}


Samples of groundwater have been collected from (15) deep wells during April 2017. Each sample was collected in plastic bottle (1000 ml). The sampling point's locations are shown in Figure (1). The $\mathrm{pH}$, electrical conductivity (EC), and total dissolved solids (TDS) were measured through using digital conductivity meters immediately after sampling in the field. The groundwater samples were analyzed in the laboratory for the major ions $(\mathrm{Ca}, \mathrm{Mg}, \mathrm{Na}, \mathrm{K}$, $\mathrm{HCO}_{3}, \mathrm{CO}_{3}, \mathrm{SO}_{4}, \mathrm{Cl}$ ) by using the standard methods as suggested by the American Public Health Association (APHA, 1999). Sodium (Na) and Potassium (K) were estimated by flame photometer. Total hardness (TH) as $\mathrm{CaCO}_{3}$, Calcium $\left(\mathrm{Ca}^{2+}\right)$, carbonate $\left(\mathrm{CO}_{3}\right)$, bicarbonate $\left(\mathrm{HCO}_{3}\right)$ were analyzed by EDTA titrimetric method. Magnesium (mg) was calculated from $\mathrm{TH}$ and $\mathrm{Ca}$ contents. Sulfates $\left(\mathrm{SO}_{4}\right)$ were determined through using colorimetric technique. Thus, the concentrations has been calculated and interpreted with some indexes of by using the SP, SAR, RSC, MH, and KR.

\section{Results and Discussion}

The results are obtained from chemical analysis of groundwater samples as shown in Table (1).

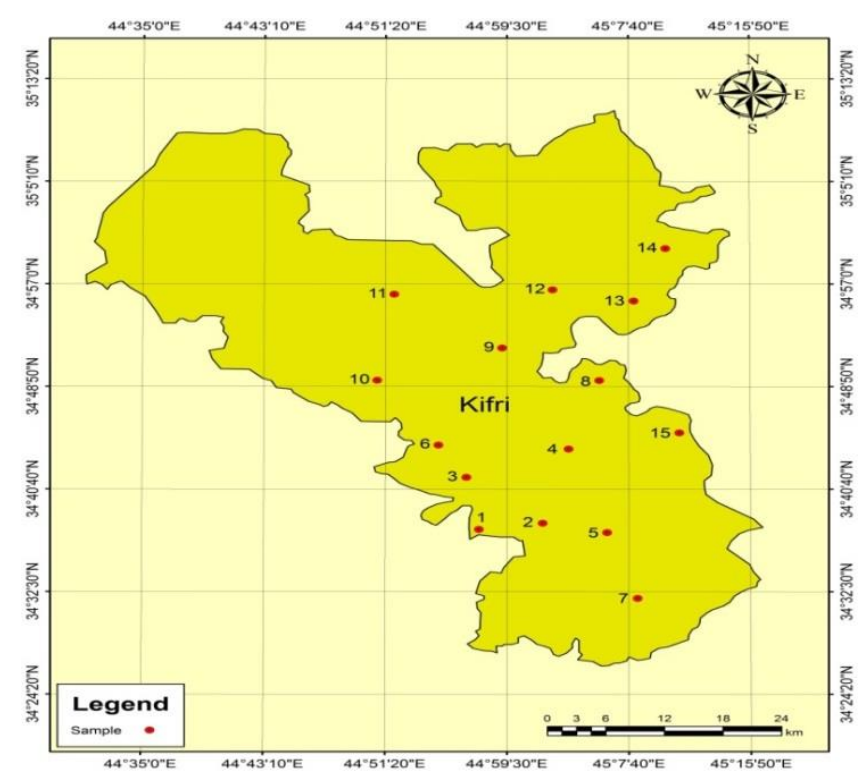

Fig.1: Location of sampling points 
مجلة جامعة كرميان

Table 1: Results of water quality analysis of groundwater samples.

\begin{tabular}{|c|c|c|c|c|c|c|c|c|c|c|c|c|c|c|c|c|c|}
\hline Well & Turbidity & $\mathrm{pH}$ & $\begin{array}{c}\mathrm{EC} \\
\mu \mathrm{s} / \mathrm{cm}\end{array}$ & $\begin{array}{c}\text { Total } \\
\text { Hardness }\end{array}$ & TDS & $\mathrm{Ca}^{+2}$ & $\mathrm{Mg}^{+2}$ & $\mathrm{Na}^{+}$ & $\mathrm{K}^{+}$ & $\mathrm{Cl}^{-}$ & $\mathrm{SO}_{4}^{-2}$ & $\mathrm{HCO}_{3}^{-}$ & SAR & $\begin{array}{l}\text { (SP) } \\
\mathrm{Na} \%\end{array}$ & $\begin{array}{l}\mathrm{Mg} \% \\
(\mathrm{MH})\end{array}$ & $\mathrm{KR}$ & $\mathrm{RSC}$ \\
\hline \multirow{2}{*}{1} & \multirow{2}{*}{1.8} & \multirow{2}{*}{8.3} & \multirow{2}{*}{1131} & \multirow{2}{*}{476} & \multirow{2}{*}{723.8} & 240 & 30.1 & 67.69 & 2.27 & 65 & 340.18 & 200.98 & 4.24 & \multirow{2}{*}{8.47} & \multirow{2}{*}{17.29} & \multirow{2}{*}{0.20} & \multirow{2}{*}{-11.24} \\
\hline & & & & & & 12.02 & 2.51 & 2.95 & 0.06 & 1.83 & 7.08 & 3.29 & 0.81 & & & & \\
\hline \multirow{2}{*}{2} & \multirow{2}{*}{2.1} & \multirow{2}{*}{8.5} & \multirow{2}{*}{1197} & \multirow{2}{*}{530} & \multirow{2}{*}{766} & 148 & 38.8 & 63.55 & 2.56 & 57 & 385.25 & 236.86 & 4.91 & \multirow{2}{*}{8.85} & \multirow{2}{*}{30.41} & \multirow{2}{*}{0.26} & \multirow{2}{*}{-6.77} \\
\hline & & & & & & 7.41 & 3.24 & 2.77 & 0.06 & 1.61 & 8.02 & 3.88 & 0.92 & & & & \\
\hline \multirow{2}{*}{3} & \multirow{2}{*}{1.2} & 86 & 1024 & 460 & 655 & 132 & 31.5 & 57.35 & 1.89 & 56 & 266.43 & 198.54 & 4.72 & 768 & 2846 & 027 & 500 \\
\hline & & 8.6 & 1024 & 460 & 655 & 6.61 & 2.63 & 2.50 & 0.05 & 1.58 & 5.55 & 3.25 & 0.89 & 1.68 & 28.46 & 0.27 & -5.99 \\
\hline 4 & 13 & 86 & 1053 & 468 & 654 & 136 & 29.1 & 55.28 & 1.5 & 49 & 278.23 & 234.55 & 4.51 & 720 & 26,20 & 02 & 5.4 \\
\hline 4 & 1.3 & 8.0 & 1053 & 408 & 634 & 6.81 & 2.43 & 2.41 & 0.04 & 1.38 & 5.8 & 3.8 & 0.85 & 1.29 & 26.29 & 0.26 & -5.44 \\
\hline 5 & 10 & 85 & 1008 & 480 & 7027 & 140 & 31.6 & 61.44 & 2.08 & 63 & 300.22 & 186.32 & 4.92 & 805 & 2734 & 028 & 660 \\
\hline 5 & 1.9 & 8.5 & 1098 & 480 & 702.7 & 7.01 & 2.64 & 2.68 & 0.05 & 1.78 & 6.25 & 3.05 & 0.93 & 8.05 & 27.34 & 0.28 & -6.60 \\
\hline 6 & 180 & 88 & 1288 & 660 & 8243 & 132 & 80.1 & 69.76 & 2.56 & 87 & 314.08 & 137.39 & 5.32 & 1284 & $50>0$ & 023 & 1105 \\
\hline 0 & 1.89 & 8.8 & 1288 & 600 & 824.3 & 6.61 & 6.69 & 3.04 & 0.06 & 2.45 & 6.54 & 2.25 & 0.96 & 12.84 & 50.29 & 0.23 & -11.00 \\
\hline 7 & 13 & 85 & 1311 & 676 & 839 & 172 & 59.7 & 69.69 & 2.63 & 84 & 280.58 & 200.01 & 4.91 & 1113 & 3665 & 022 & 1030 \\
\hline 1 & 1.3 & 8.5 & 1311 & $6 / 6$ & 839 & 8.61 & 4.98 & 3.04 & 0.06 & 2.37 & 5.84 & 3.3 & 0.91 & 11.13 & 36.65 & 0.22 & -10.30 \\
\hline 8 & 06 & 81 & 897 & 420 & 440 & 88 & 48.5 & 50 & 2 & 55 & 190.45 & 159.33 & 4.72 & 847 & 4788 & 026 & 585 \\
\hline 8 & 0.6 & 8.1 & 891 & 420 & 449 & 4.41 & 4.05 & 2.18 & 0.05 & 1.55 & 3.96 & 2.61 & 0.86 & 8.41 & 47.88 & 0.20 & -5.85 \\
\hline 0 & 00 & 77 & 1022 & 480 & 512 & 132 & 36.4 & 56 & 2.52 & 72 & 192.77 & 135.28 & 4.57 & 709 & 31.40 & 025 & 744 \\
\hline 9 & 0.9 & 7.7 & 1022 & 480 & 512 & 6.61 & 3.04 & 2.44 & 0.06 & 2.03 & 4.01 & 2.21 & 0.86 & 7.99 & 31.49 & 0.25 & -7.44 \\
\hline 10 & 08 & 76 & 1162 & 620 & 580 & 160 & 53.4 & 61 & 2.88 & 90 & 198.32 & 227.65 & 4.46 & 085 & 3575 & 021 & 875 \\
\hline 10 & 0.8 & 1.6 & 1102 & 020 & 580 & 8.01 & 4.46 & 2.66 & 0.07 & 2.54 & 4.13 & 3.72 & 0.83 & 9.83 & 35.15 & 0.21 & -8.15 \\
\hline 11 & 11 & 78 & 681 & 212 & 4364 & 58 & 16 & 23 & 0.83 & 18 & 121.5 & 200.8 & 2.83 & 3.37 & 3150 & 024 & 115 \\
\hline 11 & 1.1 & 7.8 & 681 & 212 & 436.4 & 2.90 & 1.34 & 1 & 0.02 & 0.51 & 2.53 & 3.09 & 0.53 & 3.37 & 31.50 & 0.24 & -1.15 \\
\hline 12 & 1 & 70 & 600 & 200 & 442 & 62 & 11 & 16 & 0.73 & 21 & 126 & 222.3 & 1.95 & 234 & 2282 & 017 & 061 \\
\hline 12 & 1 & 1.9 & 690 & 202 & 442 & 3.1 & 0.92 & 0.70 & 0.02 & 0.59 & 2.6 & 3.42 & 0.37 & 2.34 & 22.82 & 0.17 & -0.61 \\
\hline 13 & 12 & 82 & 541 & 356 & 346 & 100 & 28 & 16 & 2.41 & 28 & 107.8 & 230 & 1.50 & 370 & 3174 & 000 & 380 \\
\hline 13 & 1.2 & 8.2 & 541 & 356 & 346 & 5.01 & 2.33 & 0.7 & 0.06 & 0.79 & 2.25 & 3.54 & 0.28 & 3.79 & 31.74 & 0.09 & -3.80 \\
\hline 14 & 080 & 70 & 602 & 224 & 3836 & 58 & 19 & 14 & 1.29 & 30 & 65.3 & 168.3 & 1.69 & 285 & 3554 & 013 & 102 \\
\hline 14 & 0.89 & 1.9 & 002 & 224 & 383.0 & 2.9 & 1.6 & 0.61 & 0.03 & 0.85 & 1.36 & 2.59 & 0.31 & 2.83 & 30.54 & 0.13 & -1.92 \\
\hline 15 & 13 & 81 & 407 & 300 & 260 & 80 & 24.76 & 5.63 & 0.63 & 22 & 40.6 & 172 & 0.59 & 258 & 3403 & 004 & 343 \\
\hline 15 & 1.3 & 8.1 & 407 & 302 & 260 & 4.01 & 2.07 & 0.25 & 0.02 & 0.62 & 0.85 & 2.64 & 0.11 & 2.58 & 34.03 & 0.04 & -3.43 \\
\hline Min & 06 & 76 & 407 & 202 & 260 & 2.90 & 0.92 & 0.25 & 0.02 & 0.51 & 0.85 & 2.21 & 0.11 & 234 & 1720 & 004 & 1124 \\
\hline $\operatorname{Min}(\mathrm{epm})$ & 0.6 & 1.6 & 407 & 202 & 260 & 58.00 & 11 & 5.63 & 0.63 & 18.00 & 40.60 & 135.28 & 0.59 & 2.34 & 17.29 & 0.04 & -11.24 \\
\hline Max & 1 & 88 & 1311 & 676 & 830 & 240 & 80.1 & 69.76 & 2.88 & 90 & 385.25 & 236.86 & 5.32 & 1284 & $50>0$ & 028 & 061 \\
\hline $\operatorname{Max}(\mathrm{epm})$ & 2.1 & 8.8 & 1311 & 676 & 839 & 12.02 & 6.69 & 3.04 & 0.07 & 2.54 & 8.02 & 3.88 & 0.96 & 12.84 & 50.29 & 0.28 & -0.61 \\
\hline Ave. & 129 & 821 & 9403 & 4377 & 5716 & 122.5 & 35.9 & 45.8 & 1.9 & 53.1 & 213.8 & 194.0 & 2.21 & 704 & 3250 & 021 & -602 \\
\hline Ave.(epm) & & 0.21 & & & & 6.1 & 2.99 & 1.99 & 0.05 & 1.5 & 4.5 & 3.1 & 0.7 & 1.04 & 52.50 & 0.21 & -0.02 \\
\hline
\end{tabular}

كَوَقارى زانكوَى كَهلرميان

Note: The units are (epm) in grey boxes. 


\section{4:1 pH}

Both types of reactions (biological and chemical) directly relay on the $\mathrm{pH}$ of the water system. The $\mathrm{pH}$ values of the groundwater samples are ranging from (7.6-8.8) which indicates that the groundwater in the study area is slightly alkaline in nature. That is because of the $\mathrm{HCO}_{3}$ influx in the groundwater aquifer as a result of rain water percolation through soil (Alam, et al 2012). The desirable (pH) limits range for irrigation water from (6.5-8.4) (Bauder, et al. 2015).

\section{4:2 Electrical Conductivity}

Irrigation water with high (EC) value affects yield potential negatively, therefore; it is an important measure of salinity hazard to plants. Excess salinity leads to decline the osmotic activity of plants; thus, interferes with absorption of nutrients and water from the soil (Saleh et al. 1999). The quality of irrigation water can be classified in terms of the hazardous effects of total salt concentration which is expressed as electrical conductivity (EC) (Reaffirmed 2009) as shown in table (2) bellow. In respect of the study area $100 \%$ of the groundwater samples are classified as the first category with a low salt content. This may be due to the study area that is very far away from the line's shore; so, the $\mathrm{NaCl}$ accumulation level in groundwater tends to be low.

Table 2: Groundwater Quality Classification Based on Total Salt Concentration

\begin{tabular}{|c|c|}
\hline Class & Range of EC (Micromhos/cm) \\
\hline Low & Below 1500 \\
\hline Medium & $1500-3000$ \\
\hline High & $3000-6000$ \\
\hline Very High & Above 6000 \\
\hline
\end{tabular}




\section{4:3 Total Dissolved Solids (TDS)}

Electrical conductivity (EC) is considered as an approximate measure for total dissolved ions and they are both (EC and TDS) concordance (Allan and Castillo, 2007). So, any differences in the values of electric conductivity lead to change of TDS values. The TDS in the study area has value between $(260-839) \mathrm{mg} / \mathrm{l}$. Based on the table (3) it indicates that the quality of groundwater samples in the study area is in a good level for irrigation purpose.

Table 3: Groundwater Quality classification Based on (TDS)

\begin{tabular}{|l|c|}
\hline \multicolumn{1}{|c|}{ Water Type } & Range of TDS (mg/l) \\
\hline Desirable for drinking & Below 500 \\
\hline Permissible for drinking & $500-1000$ \\
\hline Useful for irrigation & $<3000$ \\
\hline Unfit for drinking and irrigation & Above 3000 \\
\hline
\end{tabular}

\section{4:4 Sodium Adsorption Ratio}

The most significant chemical parameter for predicting the suitability degree of water for irrigation is sodium which is expressed in sodium adsorption ratio (SAR). It can be calculated from the ratio of sodium to calcium and magnesium. Excess ration of sodium in irrigation water produces undesirable impacts of changing the properties of soil then reducing soil permeability (Biswas et al., 2002). However, ration of calcium and magnesium ions are very important since they are tending to counter the impact of sodium. The classification for SAR as given (Richards, 1954) in table (4), and it is recommended through the salinity laboratory of the US Department of Agriculture (Wilcox, 1948) which is calculated through using the following formula:

$$
\mathrm{SAR}=\frac{\mathrm{Na}^{+}}{\sqrt{\left(\mathrm{Ca}^{2+}+\mathrm{Mg}^{2+} / 2\right)}}
$$


Table 4: Classification of irrigation water based on SAR values (USDA, 1954).

\begin{tabular}{|l|c|}
\hline Class & (SAR) Range \\
\hline Excellent & Below 10 \\
\hline Good & $10-18$ \\
\hline Fair & $18-26$ \\
\hline Poor & Above 26 \\
\hline
\end{tabular}

In the study area, all the groundwater samples have (SAR) values ranges (4.24-5.32) which are all under excellent class and all are suitable for irrigation.

\section{4:5 Sodium Percentages}

Sodium hazard is regarded as a significant factor in irrigation water quality. It is widely utilized for assessing the acceptability of water quality for irrigation purposes (Wilcox, 1948). High concentrations of sodium in groundwater lead to produce undesirable impact that is because $(\mathrm{Na})$ reacts with soil to decrease its permeability (Todd, 1980). Thus; it will affect plant growth negatively (Vasanthavigar et, al 2010). Sodium Percentage (\% $\mathrm{Na}$ ) is calculated by using the following formula (USDA, 1954):

$$
\% \mathrm{Na}=\frac{\left(\mathrm{Na}^{+}+\mathrm{K}^{+}\right)}{\left(\mathrm{Ca}^{2+}+\mathrm{Mg}^{2+}+\mathrm{Na}^{+}+\mathrm{K}^{+}\right)} \times 100
$$

Table 5: Classification of water based on (SP) values. (Wilcox, 1955)

\begin{tabular}{|l|l|}
\hline Class & (SP)\% Range \\
\hline Excellent & Below 20 \\
\hline Good & $20-40$ \\
\hline Permissible & $40-60$ \\
\hline Doubtful & $60-80$ \\
\hline Unsuitable & Above 80 \\
\hline
\end{tabular}

It is recommended that sodium percentage (SP) should not exceed $60 \%$ in irrigation waters in order to avoid sodium accumulations which lead to break down in the physical properties of soil. The values of (SP) in groundwater samples in the 
study area are ranges from (7.29-12.84). Based on the classification for (SP) which is given in table (5), it indicates that the overall quality of groundwater in the study area is falling under excellent category.

\section{4:6 Kelly's Ratio}

This can be calculated by using the bellow equation (Kelly, 1963) as:

$$
\mathrm{KR}(\text { meq } / \mathrm{l})=\frac{\mathrm{Na}^{+}}{\left(\mathrm{Ca}^{2+}+\mathrm{Mg}^{2+}\right)}
$$

According to Kelly's ratios, groundwater is classified for irrigation as shown in the table (6). In the study area, all the groundwater samples have (KR) values with less than (1) which is fallen within the safe category; hence, the groundwater quality is suitable for irrigation.

Table 6: Classification of irrigation water based on $(\mathrm{KR})$ values.

\begin{tabular}{|l|c|}
\hline Class & (KR) Range \\
\hline Safe & Below 1 \\
\hline Unsuitable & Above 1 \\
\hline
\end{tabular}

\section{4:7 Magnesium Hazard Ratio}

The values of magnesium hazard $(\mathrm{MH})$ ratio of water for irrigation uses are calculated through using the bellow equation that was proposed by (Szabolcs and Darb, 1964):

$$
\mathrm{MH}(\mathrm{meq} / \mathrm{l})=\frac{\mathrm{Mg}^{2+}}{\left(\mathrm{Ca}^{2+}+\mathrm{Mg}^{2+}\right)} \times 100
$$

The effects will be considered as adverse effect (harmful) on the production when the values of magnesium are equal or higher than (50). The results of the groundwater samples of the study area observed that $(6.67 \%)$ of the samples have $(\mathrm{MH})$ values greater than (50). More magnesium concentration in water comparing to calcium concentration leads to deteriorate the soil structure and decrease soil productivity (Michael, 2008). 


\section{4:8 Residual Sodium Carbonate}

Residual sodium carbonate (RSC) is regarded as an important parameter to determine the suitability of water for irrigation uses (Raju et, al 2009). (RSC) is used to evaluate the hazardous impact of carbonate and bicarbonate on water quality for agricultural purpose (Eaton 1950). It is calculated by using the following formula:

$$
\mathrm{RSC}(\mathrm{meq} / \mathrm{l})=\left(\mathrm{CO}_{3}^{2-}+\mathrm{HCO}_{3}^{-}\right)-\left(\mathrm{Ca}^{2+}+\mathrm{Mg}^{2+}\right)
$$

High amounts of carbonate and bicarbonate in groundwater comparing with the amount of calcium and magnesium can also influence the acceptability of groundwater for irrigation. Moreover, when the concentration of carbonate becomes very high, it will combine with calcium and magnesium to make a number of solid materials that settle out of water (Siddiqui et al, 2005). According to the US Department of Agriculture, the classification of water for irrigation in terms of (RSC) values is presented in table (7). The results show that all the samples of groundwater in the study area were safe for irrigation.

Table 7: Classification of irrigation water based on (RSC) values (USDA, 1954).

\section{Conclusion}

\begin{tabular}{|l|c|}
\hline \multicolumn{1}{|c|}{ Class } & Range of RSC $(\mathbf{m e q} / \mathbf{L})$ \\
\hline Safe & Below 1.25 \\
\hline Marginal & $1.25-2.5$ \\
\hline Unsuitable & Above 2.5 \\
\hline
\end{tabular}

Assessment of the groundwater quality of Kifri district has been carried out for their suitability for irrigation purpose. Generally, the parameters of irrigation quality namely EC, SAR, RSC, MH ratio, \%Na, KR values were calculated. All the groundwater samples have $\mathrm{SAR}<10$ which is indicating water class to be excellent. In respect of RSC, all the samples have values less than the permissible 1.5. Approximately $(6.67 \%)$ of the samples have $(\mathrm{MH})$ values greater than (50). This is the only observed problem of groundwater quality within the study area. Therefore, it is concluded that most of the parameters are within the permissible. 


\section{References}

Alam, M, Rais, S and Aslam, M 2012, "Hydrochemical Investigation and Quality Assessment of Ground Water in Rural Areas of Delhi, India", Environmental Earth Sciences, Vol.(66), pp.(97-110), available at: http://dx.doi.org/10.1007/s12665-011.

Allan, JD and Castillo, MM 2007, "Stream Ecology, Structure and Function of Running Waters", $2^{\text {nd }}$ edit., Springer, Netherlands, pp.(444).

American Public Health Association (APHA) 1995 "Standard methods for the examination of water and wastewater0", $19^{\text {th }}$ Edition, Washington, D.C, pp.(1467).

Bauder, TA, Waskom RM, and Davis JG 2015, "Irrigation Water Quality Criteria", Colorado State University, USA.

Biswas SN, Mohabey H, Malik ML 2002, "Assessment Of The Irrigation Water Quality Of River Ganga In Haridwar District", Asian J. Chem, Vol.(16).

Eaton, FM 1950, "Significance of carbonates in irrigation waters", Soil Science, Vol.(69), pp.(123-133).

Güler, C, Thyne, GD, McCray, JE and Turner, AK 2002, "Evaluation of graphical and multivariate statistical methods for classification of water chemistry data", Hydrogeology Jour, Vol. (10), pp.(455 - 474).

Kelly WP 1963, "Use of Saline Irrigation Water". Soil Sci., Vol.(95), Issue (4), pp.(35-39).

Michael, AM 2008, "Irrigation Theory and Practice", $2^{\text {nd }}$ edition, Vikas Publishing House, Pvt. Ltd., New Delhi.

Reaffirmed 2009, "Guidelines for the quality of irrigation water", BIS, New Delhi.

Raju, NJ, Ram, P and Dey, S 2009, "Groundwater Quality in the Lower Varuna River Basin, Varanasi District, Uttar Pradesh, India". Journal of the Geological Society of India, Vol. (7), pp.(178-192), available at: http://dx.doi.org/10.1007/s12040-008.

Richards LA 1954, "Diagnosis and Improvement of Saline and Alkali Soils" USDA and IBH Pub, Coy Ltd., New Delhi, India, Agric. Handbook, pp.(98-99). 
Saleh A, Al-Ruwaih F, Shehata M 1999, "Hydrogeochemical processes operating within the main aquifers of Kuwait", J Arid Environ, Vol. (42), pp. (195-209).

Siddiqui, A, Naseem, S and Jalil, T 2005, "Groundwater Quality Assessment in and around Kalu Khuhar, Super Highway, Sindh, Pakistan", Journal of Applied Sciences, Vol. (5), pp.(1260-1265), available at: http://dx.doi.org/10.3923/jas.2005.1260.1265.

Szabolcs, I and Darb, C 1964, "The influence of irrigation water of high sodium carbonate on soils",Proc. $8^{\text {th }}$ Int. Cong. Of ISSS, Trans. II, pp.(803).

Talukder MSU, Shirazi SM, Paul UK 1998, "Suitability of Groundwater for Irrigation at Kirimganj Upazila Kishoreganj", Progress Agric, Vol. (9), pp.(107-112).

Todd, DK 1980, "Ground Water Hydrology", Wiley, New York, pp. (535).

United States Department of Agriculture (USDA Salinity lab.) 1954, "Diagnosis and improvement of saline and Alkali soils", Agriculture and Drainage Lab.Tech, Report.

Vasanthavigar, M, Srinivasamoorthy, K, Vijayaragavan, K, Rajiv Ganthi, R, Chidambaram, S, Anandhan, P, Mani vannan, R and Vasudevan, S 2010, "Application of Water Quality Index for Groundwater Quality Assessment: Thirumanimuttar Sub-Basin, Tamilnadu, India, Environmental Monitoring and Assessment", Vol.(171), pp.(595-609), available at:

http://dx.doi.org/10.1007/s10661-009-1302-1.

Wilcox LV 1955, "Classification and Use of Irrigation Water", Washington: US Department of Agriculture, Circular No.(969), pp. (19).

Wilcox, LV 1948, "Classification and Use of Irrigation Waters", U.S. Department of Agriculture, Washington DC, pp.(962).

World Health Organization (WHO), 2004, "Guideline for Drinking Water Quality", $3^{\text {rd }}$ edit., Vol.(1), Geneva, pp. (515) 